\author{
KATARZYNa PISZCZATOWSKA, GRAŻYNA MOSIENIAK
}

Pracownia Molekularnych Podstaw Starzenia

Instytut Biologii Doświadczalnej PAN

Pasteura 3, 09-093 Warszawa

E-mail: g.mosieniak@nencki.gov.pl

\title{
OKSYDAZY NADPH JAKO ATRAKCYJNY CEL TERAPII PRZECIWNOWOTWOROWEJ
}

\section{WSTEP}

Oksydazy NAPH (NOX) to grupa enzymów produkujacych reaktywne formy tlenu (RFT). Obecność NOX odnotowano zarówno w tkankach zdrowych, jak i zmienionych nowotworowo. Działanie RFT jest bardzo różnorodne. $Z$ jednej strony biora udział $\mathrm{w}$ przekazywaniu sygnałów komórkowych, przez co uczestnicza $\mathrm{w}$ wielu procesach, $\mathrm{np}$. proliferacji, różnicowaniu, migracji, $z$ drugiej, moga przyczyniać się do uszkodzenia struktur komórkowych. Zauważono także, że NOX posiadaja zwiazek $z$ procesem starzenia. Starzenie komórkowe jest procesem niezwykle interesujacym i ważnym $\mathrm{w}$ organizmie człowieka. Zjawisku temu ulega większość komórek prawidłowych. Wiaże się ono $z$ trwałym zahamowaniem podziałów komórkowych, co w przypadku komórek budujacych tkanki naszego organizmu prowadzi do zmniejszonej możliwości regeneracji tkanek oraz w konsekwencji do upośledzenia ich funkcjonowania, co obserwuje się w starzejacym organizmie. W zwiazku $z$ tym, próbuje się zapobiegać lub opóźniać proces starzenia w nadziei, że w ten sposób możliwe będzie spowolnienie niepożąanych zmian zachodzacych wraz $z$ wiekiem. Istnieje jednak grupa komórek, których proliferację chcielibyśmy zahamować. Sa nimi komórki nowotworowe, pozostajace "wiecznie młode" ze względu na to, że nie traca zdolności do podziałów wraz $z$ upływem czasu. Okazuje się, iż pod wpływem określonych czynników również one moga ulec procesowi starzenia. Zaobserwowana zwiększona aktywność oksydaz
NADPH w tkankach nowotworowych oraz opisywany $\mathrm{w}$ literaturze ich udział $\mathrm{w}$ regulacji proliferacji i starzenia komórkowego sprawia, że enzymy te moga stanowić atrakcyjny cel terapii przeciwnowotworowej prowadzacej to trwałego zahamowania proliferacji komórek nowotworowych.

\section{RODZINA OKSYDAZ NADPH}

Rodzinę oksydaz NADPH (NOX) stanowia białka przenoszace elektrony poprzez błony biologiczne. NADPH oksydazy katalizuja powstanie anionorodnika ponadtlenkowego (bądź nadtlenku wodoru w przypadku NOX4) na drodze jednoelektronowej redukcji tlenu. Donorem elektronu jest NADPH lub NADH. Biologiczna funkcja enzymów należących do tej rodziny to właśnie produkcja reaktywnych form tlenu (BEDARD i KRAUSE 2007). Jednak rola jaka pełnia reaktywne formy tlenu produkowane przez oksydazy NADPH jest zróżnicowana $\mathrm{w}$ zależności od typu komórki, miejsca ich powstawania i ich liczby. Reaktywne formy tlenu biora udział $\mathrm{w}$ przekazywaniu sygnałów $\mathrm{w}$ komórce. Ich aktywność związana jest $z$ regulacją wielu procesów. Niestety wiadomo, że moga przyczyniać się także do uszkodzenia różnych cząsteczek, np. DNA czy lipidów. Wszystkie enzymy należące do grupy oksydaz NADPH mają podobna strukturę. Zbudowane sa $z$ sześciu domen transbłonowych. Domeny III i V zawieraja dwie histydyny w obrębie dwóch asymetrycznych reszt hemowych. Obecny w cytoplazmie, majacy grupe - $\mathrm{COOH}$ koniec posiada dinukleotyd flawino- 
adeninowy (FAD) i domenę wiążaca NADPH. Uważa się, że NOX transportuja pojedynczy elektron od NADPH do FAD, następnie do pierwszego hemu, po czym do hemu drugiego, a stamtad ostatecznie na tlen (BEDARD i KRAUSE 2007).

W komórkach ludzkich zidentyfikowano 7 oksydaz NADPH: NOX1, NOX2, NOX3, NOX4, NOX5, DUOX1 i DUOX2. Choć początkowo ich obecność wykazywano tylko w komórkach układu odpornościowego i wiązano $z$ procesem tzw. wybuchu tlenowego, którego efektem jest zabicie patogenu, to obecnie wiadomo, że ekspresja tych enzymów jest powszechna w różnych typach komórek, a spektrum działania bardzo szerokie i czasami przeciwstawne (PRZYBYLSKA i MoSIENIAK 2014) (Ryc. 1). Z wyjątkiem NOX5, aktywacja wszystkich niezwiazanych $z$ fagocytozą enzymów $z$ rodziny oksydaz NADPH potrzebuje współpracujących $z$ nimi białek (CROSS i SEgAL 2004). Na przykład w celu osiagnięcia pełnej aktywności NOX1 tworzy kompleks $z$ występującym w błonie białkiem p22 $2^{\text {phox }}$ oraz rozpuszczalnymi podjednostkami

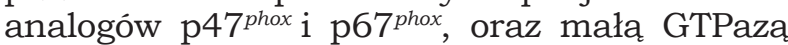
Rac1.

Ekspresja genu NOX1 pojawia się w zdrowym i zmienionym nowotworowo nabłonku okrężnicy oraz w mniejszym stopniu w mięśniach gładkich naczyń krwionośnych $i$ innych tkankach prawidłowych. NOX3 wykorzystuje do współpracy te same białka, jednak jego występowanie ograniczone jest do nabłonka czuciowego ślimaka i błędnika obecnych w uchu wewnętrznym. Jego aktywność wiąże się także $z$ biogeneza otolitu (kamyczka błędnikowego) odgrywającego rolę w percepcji grawitacji i równowagi (CHENG i współaut. 2004, UENO i współaut. 2005). NOX2 jest to pierwszy opisany członek rodziny oksydaz NADPH. Występuje w fagocytach i jej aktywność wiąże się $z$ wybuchem tlenowym, który skutkuje zabiciem patogenów (RoY i współaut. 2015). NOX4 występuje w korze nerek i komórkach śródbłonkowych. Ekspresja genu kodujacego NOX4 na niższym poziomie obserwowana jest również w kardiomiocytach, adipocytach i mięśniach szkieletowych (YAMAURA i współaut. 2009). Badania poziomu transkryptu genu NOX5 pozwoliły na stwierdzenie jego obecności w spermatocytach, mięśniach gładkich macicy, bogatych w limfocyty obszarach śledziony i węzłach chłonnych bogatych w dojrzałe limfocyty B i T. Oprócz tego NOX5 pojawia się $\mathrm{w}$ jajnikach, łożysku, fibroblastach w sercu (JUHAsz i współaut. 2009). Obecność mRNA DUOX1 wykazano w śródbłonku oddechowym, w którym odgrywa krytyczna rolę w obronie gospodarza, w tarczycy, gdzie produkcja $\mathrm{H}_{2} \mathrm{O}_{2}$ przez ten enzym jest ważna dla syntezy hormonów tarczycowych (JUHASz i współaut. 2009). DUOX2 poczatkowo opisywany był jako enzym produkujacy $\mathrm{H}_{2} \mathrm{O}_{2}$ w tarczycy i zwiazany $z$ biogeneza hormonów tarczycowych (CAILlOU i współaut. 2001). Późniejsze badania podkreślały jego obronna rolę w nabłonku oskrzeli i całym przewodzie pokarmowym.

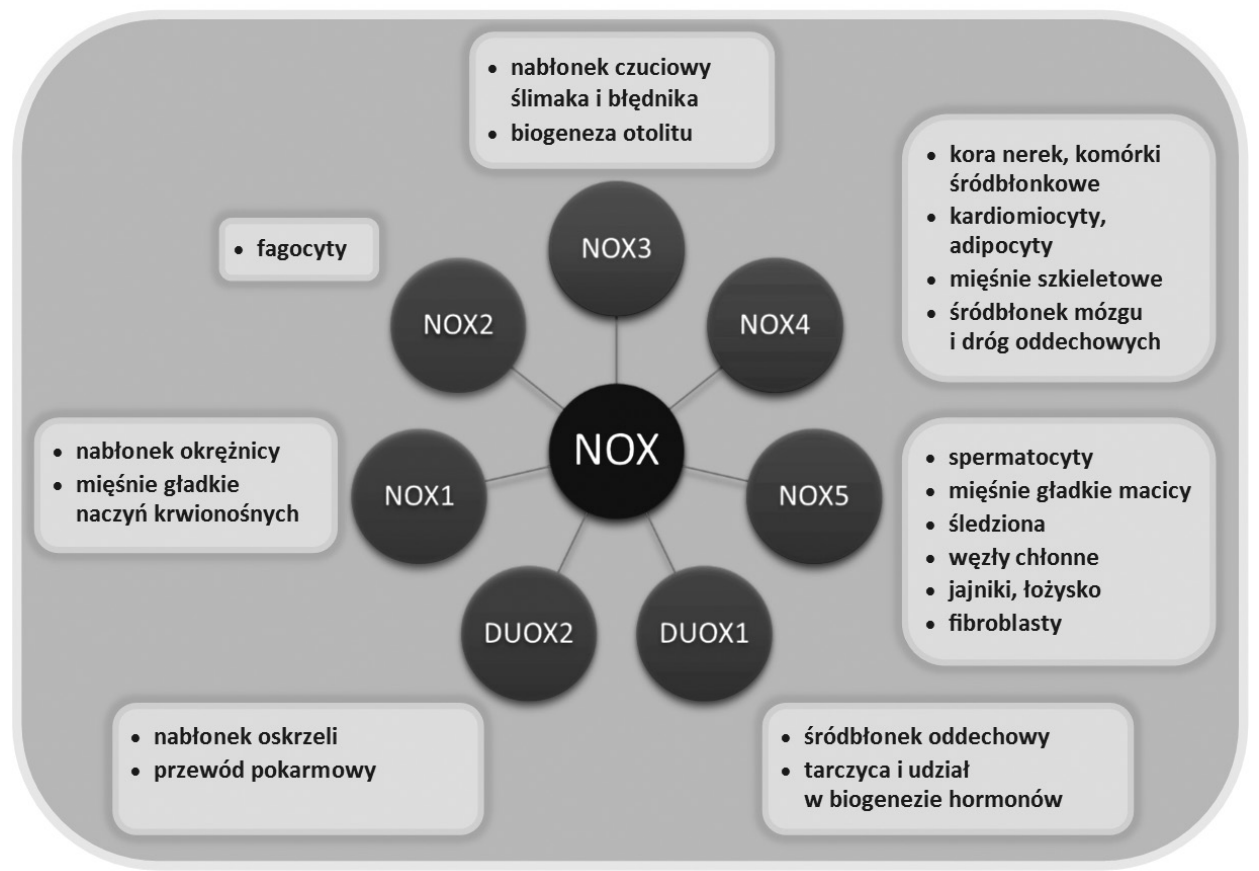

Ryc. 1. Występowanie oksydaz NADPH (NOX) w tkankach organizmu. 


\section{REAKTYWNE FORMY TLENU I OKSYDAZY NADPH (NOX) A NOWOTWORY}

Udział reaktywnych form tlenu w procesie transformacji nowotworowej postulowany był już w latach 80. ubiegłego wieku, kiedy to OBERLEY i współaut. (1981) opublikowali wyniki badań, w których wykazali wzrost poziomu nadtlenku wodoru w komórkach stymulowanych do proliferacji insuliną. Jednocześnie sformułowali oni wówczas tzw. wolnorodnikowa teorie nowotworzenia, która zakładała, że zwiększona produkcja wolnych rodników prowadzi do unieśmiertelnienia komórek. Dalsze badania, które najpierw doprowadziły do odkrycia enzymów produkujacych RFT-NOX, jako białek powszechnie wystepujacych w różnych typach komórek, dowiodły również, że oksydazy NADPH sa istotnym źródłem RFT w wielu różnych liniach komórek nowotworowych (SZATROWSKI i NATHAN 1991). Co więcej, ich podwyższony poziom odnajdywano w różnych typach nowotworów (Tabela 1).

Wysoki poziom RFT może przyspieszać wzrost i rozwój nowotworu uruchamiając kilka różnych mechanizmów. Po pierwsze, RFT działaja mutagennie i przyczyniaja się do wzrostu niestabilności genetycznej, która promuje proces transformacji nowotworowej. Udowodniono, że produkowane przez NOX reaktywne formy tlenu przyczyniaja się do utlenienia zasad azotowych, szczególnie guaniny, jak również do przerwania nici DNA w komórkach nowotworowych, powodując genetyczna heterogenność (RoY i współaut. 2015). Wiadomo też, że utlenienie zasad azotowych występujących w kwasie deoksyrybonukleinowym jest jedna $z$ najbardziej powszechnych przyczyn mutacji somatycznych w guzach litych. Fakt stwierdzenia obecności oksydazy NOX4 w błonie jądrowej nasuwa przypuszczenie, że produkowany przez nią nadtlenek wodoru może bezpośrednio uszkadzać DNA jądrowy (SPENCER i współaut. 2011). Ponadto, oksydaza ta występuje również w błonie mitochondrialnej i, jak wykazały badania KozIELA i współaut. (2013), może ona poprzez inaktywację kompleksu I zaburzać prawidłowe funkcjonowanie mitochondriów. W efekcie dochodzi do zwiększenia oksydacyjnych uszkodzeń mitochondrialnego DNA, co przyczynia się do wzrostu stresu oksydacyjnego w całej komórce.

Kolejnym mechanizmem działania NOX, który może wywierać efekt pronowotworowy, jest udział tych enzymów w regulowaniu prożyciowych i proproliferacyjnych ścieżek przesyłania sygnału w komórce. Uważa się, że w odpowiedzi na mitogeny dochodzi do aktywacji oksydaz NADPH, które poprzez produkcje RFT wpływaja na ścieżki przesyłania sygnału regulujące cykl komórkowy. Tak np. wykazano związek pomiędzy działaniem płytkowego czynnika wzrostu (PDGF) oraz naskórkowego czynnika wzrostu (EGF) a wzrostem poziomu RFT produkowanych $z$ udziałem NOX1

Tabela 1. Występowanie poszczególnych oksydaz NADPH w różnych typach nowotworów.

\begin{tabular}{|c|c|c|}
\hline $\begin{array}{l}\text { Oksydaza } \\
\text { NADPH }\end{array}$ & Typ nowotworu-występowanie & Referencje \\
\hline NOX1 & rak okrężnicy, & JUHASZ i współaut. 2009, DOROSHOW i \\
\hline NOX2 & $\begin{array}{l}\text { niedrobnokomórkowy rak płuc, gruczolak żołądka } \\
\text { nowotwory pochodzenia hematopoetycznego }\end{array}$ & $\begin{array}{l}\text { współaut. 2012, RoY i współaut. } 2015 \\
\text { JuHASz i współaut. 2009, DoROSHOw i } \\
\text { współaut. } 2012\end{array}$ \\
\hline NOX3 & nie zaobserwowano & $\begin{array}{l}\text { JUHASZ i współaut. 2009, DOROSHOw i } \\
\text { współaut. } 2012\end{array}$ \\
\hline NOX4 & $\begin{array}{l}\text { nowotwory jajnika, nerek, mózgu, czerniak, gruczo- } \\
\text { lak żołądka }\end{array}$ & $\begin{array}{l}\text { JUHASZ i współaut. 2009, YAMAURA i współ- } \\
\text { aut. 2009, DoROSHOw i współaut. 2012, } \\
\text { RoY i współaut. } 2015\end{array}$ \\
\hline NOX5 & $\begin{array}{l}\text { rak piersi, przełyku, prostaty, białaczka włochato- } \\
\text { komórowa, czerniak, } \\
\text { niedrobnokomórkowy rak płuc }\end{array}$ & $\begin{array}{l}\text { JUHASZ i współaut. 2009, DoROSHOw i } \\
\text { współaut. } 2012\end{array}$ \\
\hline DUOX1 & $\begin{array}{l}\text { niska ekspresja w nowotworach ludzkich, rak } \\
\text { trzustki }\end{array}$ & $\begin{array}{l}\text { JUHASZ i współaut. 2009, DoROSHOw i } \\
\text { współaut. } 2012\end{array}$ \\
\hline DUOX2 & rak płuc, tarczycy, okrężnicy, trzustki & $\begin{array}{l}\text { JUHASZ i współaut. 2009, DoRoshow i } \\
\text { współaut. 2012, Wu i współaut. } 2013\end{array}$ \\
\hline
\end{tabular}


(PARK i współaut. 2004), czy też zwiększoną aktywność NOX4 pod wpływem działającego na komórki TGF- $\beta$ (STURROCK i współaut. 2007). Jedna $z$ grup czasteczek, których aktywność podlega regulacji zależnej od RFT i które odgrywaja istotna role w przekazywaniu sygnału od receptorów czynników wzrostowych sa fosfatazy. Posiadaja one wrażliwe na utlenienie reszty cysteinowe. W efekcie takiego utlenienia dochodzi do przejściowego zahamowania aktywności fosfatazy, co pozwala na utrzymujaca się fosforylację kinaz receptorowych i aktywację białek docelowych (RAY i współaut. 2012). Wykazano na przykład, że pod wpływem działania EGF w komórkach śródbłonka naczyń dochodzi do aktywacji NOX4 i wzrostu RFT, które prowadza do utlenienia reszt cysteinowych i zahamowania aktywności fosfatazy PTP1B (CHEN i współaut. 2008). Podobnej regulacji, zależnej od utlenienia reszt cysteinowych, podlegają również inne białka sygnałowe, takie jak czynniki transkrypcyjne i kinazy (RAY i współaut. 2012), dlatego też udział enzymów NOX w regulacji proliferacji może przebiegać poprzez szereg różnych białek. Podwyższony poziom NOX $\dot{i}$ produkowanych przez nie RFT poprzez zahamowanie aktywności fosfataz, przyczyniają się do przedłużonej fosforylacji i zwiększonej aktywacji kinaz receptorów dla czynników wzrostowych. W efekcie w komórce generowany jest sygnał do proliferacji, który nie podlega właściwej regulacji. Tak na przykład wykazano, że stała aktywność enzymów NOX w komórkach linii nowotworowych HepG2 i A431 prowadzi do utlenienia reszt cysteinowych obecnych w centrum aktywnym fosfatazy PTP1B. Zahamowanie aktywności NOX inhibitorem DPI prowadziło do obniżania poziomu fosforylacji reszt tyrozynowych i ograniczało niezależny od podłoża wzrost komórek nowotworowych (LOU i współaut. 2008).

Opisywany był również udział RFT produkowanych przez enzymy NOX w komórkach nowotworowych w regulacji prożyciowych ścieżek przesyłania sygnału. Wykazano zależność pomiędzy RFT a zwiększona aktywnością kinaz szlaków JAK/STAT i PI3K/AKT oraz czynników transkrypcyjnych NFkB i p53 (BLOCK i GORIN 2012).

Oksydazy NADPH uczestnicza również w ścieżce przesyłania sygnału generowanego przez onkogen RAS. Nadekspresja KRAS indukuje ekspresję NOX1 w kilku różnych typach komórek. Ponadto wykazano, że RFT produkowane przez NOX1 sa niezbędne w transformacji nowotworowej wywołanej onkogenem RAS oraz do wzrostu guzów w mysim modelu kancerogenezy (Mitsushita i współaut. 2004).

Obecne na podwyższonym poziomie w komórkach nowotworowych oksydazy NADPH promuja procesy związane $Z$ angiogeneza, co jest niezbędne do wzrostu guzów. Wykazano, że RFT produkowane przez NOX1 i NOX4 były odpowiedzialne za zwiększona ekspresję genu kodującego czynnik wzrostu śródbłonka naczyniowego (VEGF), który wydzielany przez komórki nowotworowe czerniaka, stymuluje tworzenie nowych naczyń w obrębie guza (ARBISER i współaut. 2002).

W hodowli komórkowej NOX1 odgrywa również ważną rolę w migracji komórek nowotworowych, w której pośredniczy a-integryna, oraz w sygnalizacji poprzez ścieżkę Wnt uważana za krytyczną w rozwoju zarówno raka okrężnicy, jak i czerniaka (RoY i współaut. 2015).

Podsumowujac, istnieje szereg badań wskazujacych, że zwiększona ekspresja NOX odgrywa istotna rolę zarówno w procesie transformacji nowotworowej, jak i w promowaniu proliferacji komórek nowotworowych oraz wzrostu guza. Z tego też powodu oksydazy NADPH stanowia atrakcyjny cel terapeutyczny, co jest przedmiotem licznych badań.

\section{OKSYDAZY NADPH A ŚMIERĆ KOMÓRKOWA I STARZENIE}

Wiele przeprowadzonych badań wskazuje na śmierć komórkowa w odpowiedzi na aktywację NOX. Reaktywne formy tlenu moga przyczyniać się do apoptozy (i) pośrednio poprzez uszkodzenia DNA i lipidów lub (ii) bezpośrednio przez czasteczki sygnałowe aktywowane przez RFT. Sygnal proapoptotyczny może pojawiać się dzięki aktywacji kinaz MAP, takich jak SAPK/JNK, ERK1/2 i p38. Aktywacja kinaz MAP występuje w wielu przypadkach na drodze zależnego od RFT zahamowania fosfatazy tyrozynowej. Przy wyższym stężeniu RFT, nadtlenek wodoru może hamować kaspazy i w ten sposób prowadzić do zmiany apoptozy w nekrozę (BEDARD i KRAUSE 2007).

Zauważono jednak, że w pewnych warunkach produkowane przez NOX reaktywne formy tlenu wywieraja efekt prożyciowy. Pochodzace od NOX reaktywne formy tlenu moga działać antyapoptotycznie aktywując czynnik transkrypcyjny NF-kB lub kaskadę kinaz Akt/ASK1. Sugeruje się również, $\dot{z}$ e nadtlenek jest naturalnym inhibitorem śmierci komórkowej zależnej od receptora Fas (BEDARD i KRAUSE 2007). Zatem aktywacja NOX może prowadzić do śmierci komórkowej, jednak w pewnych warunkach 
może być czynnikiem antyapoptotycznym. Możliwych przyczyn tych pozornie sprzecznych funkcji oksydaz NADPH można doszukiwać się w: różnym poziomie produkowanych RFT, zróżnicowanej ekspresji i rozmieszczeniu poszczególnych izoform NOX, komórkowo-specyficznym zestawie wrażliwych na zmiany oksyredukcyjne białek (np. czynników transkrypcyjnych, kinaz, fosfataz, kaspaz) obecnych w danym typie komórek oraz metabolizmie anionorodnika ponadtlenkowego (który może działać antyapoptycznie) w stosunku do nadtlenku wodoru (którego działanie może być proapoptyczne) (PERVAIZ i Cle’Ment 2002).

Zauważono, że RFT produkowane przez oksydazy NADPH moga prowadzić do starzenia komórkowego zgodnie $z$ opisywana w literaturze prostarzeniowa rola tych czasteczek (LENER i współaut. 2009, WEYEMI i współaut. 2011, KoDAMA i współaut. 2012).

\section{CZYM JEST STARZENIE KOMÓRKOWE?}

Każda prawidłowa komórka przechodzi liczne podziały, które odgrywają istotna rolę w prawidłowym funkcjonowaniu zarówno tkanek, jak i całego organizmu, jego wzrostu i regeneracji. W 1961 r. Hayflick i Moorhead, prowadzac badania na fibroblastach udowodnili, że komórki hodowane in vitro moga dzielić się tylko przez pewien czas, po czym zaprzestają podziałów, mimo iż warunki w których sa hodowane zapewniaja im dostęp do wszystkich czynników wzrostowych potrzebnych do proliferacji (HAYFLICK i MOORHEAD 1961). Maksymalna liczbę podziałów, którym ulegaja tak hodowane komórki określa się jako tzw. limit Hayflicka, który może być różny w zależności od typu komórek. Opisane powyżej zjawisko zwiazane $z$ wyczerpywaniem potencjału proliferacyjnego komórek, zaobserwowane i opisane przez Hayflicka i Moorheada nazywa się starzeniem komórkowym. Starzejaca się komórka pomimo tego, iż jest żywa i aktywna metabolicznie traci nieodwracalnie zdolność do podziałów komórkowych.

Proces starzenia komórkowego, choć odkryty dzieki obserwacjom prowadzonym in vitro, zachodzi również w tkankach naszego organizmu. Akumulacja komórek starych towarzyszy starzeniu organizmu oraz chorobom zwiazanym $z$ wiekiem, takim jak cukrzyca czy choroby układu krażenia. Ostatnie badania prowadzone na organizmach modelowych dowiodły, że starzenie komórkowe może wręcz być odpowiedzialne za postępująca $Z$ wiekiem dysfunkcję różnych organów i tkanek (BAKER i współaut. 2012, 2016). Starzenie komórkowe może również pełnić w organizmie pozytywna rolę. Wykazano, że stanowi ono barierę przeciwnowotworowa, która zdrowa komórka musi pokonać zanim przekształci się w komórkę nowotworową.

\section{JAKIE SA RODZAJE STARZENIA KOMÓRKOWEGO?}

\section{STARZENIE REPLIKACYJNE}

Opisany przez Hayflicka i Moorheada proces określa się jako tzw. starzenie replikacyjne. Dalsze badania przeprowadzone przez WATSONA (1972) udowodniły, że stopniowa utrata zdolności do podziałów komórkowych wynika ze skracania, wraz $z$ każdym podziałem, telomerów mieszczących się na zakończeniach chromosomów. Telomery sa to struktury występujące na końcach chromosomów komórek eukariotycznych, do skracania których dochodzi na skutek tzw. problemu końca replikacji (BIELAK-ŻMIJEWSKA i współaut. 2014). Obecność telomerów jest niezwykle ważna do prawidłowego funkcjonowania komórki. Istnieje grupa komórek posiadajacych aktywny enzym telomerazę, który jest w stanie odbudować skrócone telomery (SHAY i BACCHETTI 1997). Jego działanie obserwuje się w komórkach embrionalnych i w komórkach linii płciowej u mężczyzn. W komórkach somatycznych aktywność telomerazy jest bardzo niska, $z$ nielicznymi wyjątkami, takimi jak komórki macierzyste skóry, komórki hematopoetyczne, komórki krypt jelitowych czy aktywowane limfocyty. Dzięki temu komórki te są w stanie dzielić się wielokrotnie przez długi czas. Poza tym wykazano, iż wysoka aktywność telomerazy wykazuje aż 90\% typów nowotworów (GREIDER i BLACKBURN 1985). Proces reaktywacji telomerazy jest jednym $z$ istotnych etapów transformacji nowotworowej komórek prawidłowych. Sprawia on, że komórki stają się unieśmiertelnione $i$ nie podlegaja limitowi Hayflicka dzielacc się nieograniczona liczbę razy. Sprzyja to powstawaniu kolejnych mutacji, które prowadzić moga między innymi do nabywania oporności na stosowane terapie przeciwnowotworowe. Komórki nowotworowe nie ulegaja starzeniu replikacyjnemu, natomiast pod wpływem pewnych czynników moga ulegać starzeniu przyspieszonemu.

\section{STARZENIE PRZYSPIESZONE}

Starzenie komórkowe może być również indukowane różnymi czynnikami stresowymi, za które uważa się między innymi promieniowanie jonizujace, wolne rodniki, uszkodzenia DNA czy tzw. stres hodowlany zwiazany $z$ niefizjologicznymi warunkami na jakie narażone sa komórki w hodowli in vitro (Collado i SerRano 2006). Taki proces określa się mianem starzenia przyspieszone- 
go. W przeciwieństwie do starzenia replikacyjnego, ten typ starzenia może być indukowany również w komórkach nowotworowych, np. pod wpływem chemioterapii lub radioterapii.

Starzenie przyspieszone nie jest zwiazane ze skracaniem telomerów, które występuje w starzeniu replikacyjnym. W hodowli komórkowej obserwuje się je już po kliku dniach od zadziałania czynnika indukujacego, w przeciwieństwie do starzenia replikacyjnego pojawiającego się po miesiącach. Wspólnym mianownikiem różnorodnych czynników wywołujacych starzenie przyspieszone sa uszkodzenia DNA w formie pęknięcia obydwu nici helisy. Tak na przykład stres oksydacyjny prowadzi do pojawiania się jednoniciowych pęknięć DNA, które w czasie replikacji bywają przekształcane w pęknięcia dwuniciowe (SEDELNIKOVA i współaut. 2010). Wśród czynników uszkadzających DNA znajduje się duża grupa chemioterapeutyków stosowanych powszechnie w leczeniu. Jednym $z$ nich jest doxorubicyna. W Pracowni Molekularnych Podstaw Starzenia Instytutu Biologii Doświadczalnej im. M. Nenckiego PAN wykazano, iż podawanie komórkom tego zwiąku prowadzi do starzenia się zarówno komórek prawidłowych, jak i komórek nowotworowych (ŚLIWIŃSKA i współaut. 2009, MOSIENIAK i współaut. 2015, STRZESZEWSKA i współaut. 2018).

Szczególnym rodzajem starzenia przyspieszonego, o ogromnym znaczeniu dla prawidłowego funkcjonowania organizmu, jest starzenie indukowane onkogenami. Pionierskie badania prowadzone w latach 90. przez SERRANO i współaut. (1997) na fibroblastach pokazały, że starzenie komórkowe może być wynikiem ekspresji onkogenu Ras. Inne prace wskazują, że również nadekspresja takich onkogenów jak: RAF, MEK, MOS, BRAF

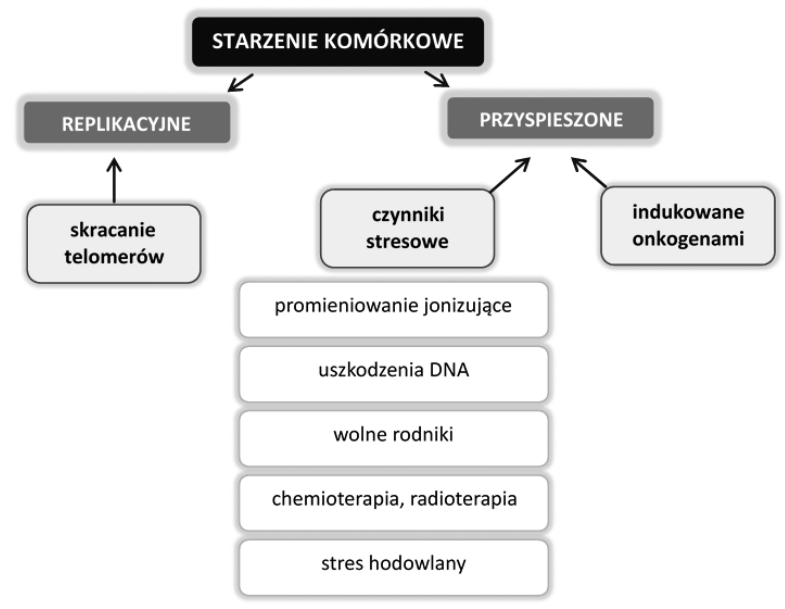

Ryc. 2. Schemat przedstawiajacy rodzaje starzenie komórkowego oraz czynniki, które je indukuja. przyczynia się do indukcji tego procesu. Udowodniono, iż starzenie indukowane onkogenami zachodzi nie tylko w warunkach hodowli in vitro, ale też in vivo, zarówno $\mathrm{u}$ ludzi, jak i u myszy. Co ważniejsze, stanowi ono istotna barierę na drodze do transformacji nowotworowej (MOSIENIAK i STRZESZEWSKA 2014) (Ryc. 2).

\section{CECHY KOMÓREK STARYCH}

Komórki stare różnią się pod względem morfologicznym i funkcjonalnym od komórek młodych. Dlatego też, w celu ich identyfikacji zarówno $\mathrm{w}$ hodowli, jak i w tkance, stosuje się kilka markerów.

\section{ZMIANY WYSTĘPUJĄE NA POZIOMIE STRUKTURY I MORFOLOGII}

Komórka, która uległa procesowi starzenia, ma zdecydowanie większe rozmiary niż komórka młoda. Mówi się o jej tzw. rozpłaszczeniu, które można obserwować w warunkach hodowli in vitro. Zmiany dostrzegalne są również w jądrze komórkowym, np. jego kształcie. Jądra komórek starych bywaja pofragmentowane lub pojedynczemu jądru towarzyszy tzw. mikrojądro powstajace w wyniku nieprawidłowego rozdziału chromosomów do komórek potomnych. Obserwuje się liczne ziarnistości oraz zwiększona liczbę lizosomów i wakuol. Pojawia się także wzrost poziomu lipofuscyny brazowożółtego barwnika wytwarzanego $\mathrm{w}$ procesie utleniania lipoprotein w lizosomach (GEORGAKOPOULOU i współaut. 2013).

W komórkach, które uległy starzeniu replikacyjnemu bądź przyspieszonemu znaczaco rośnie aktywność zwiąanej ze starzeniem kwaśnej $\beta$-galaktozydazy (SA- $\beta$-galaktozydaza) (ALSTER i KORWEK 2014) (Ryc. 3).

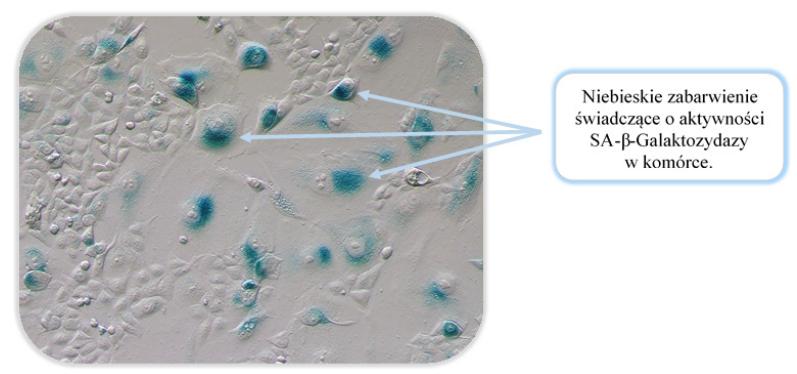

Ryc. 3. Komórki nowotworowe raka okrężnicy HCT116 które uległy starzeniu pod wpływem chemioterapeutyku - doksorubicyny. Dzięki zastosowanemu testowi cytochemicznemu $z$ wykorzystaniem substratu galaktozydazy, komórki o podwyższonej aktywności SA- $\beta$-galaktozydazy (komórki stare) zabarwiaja się na niebiesko. 


\section{ZNACZNIKI ZWIAZZANE Z PROLIFERACJA I REGULACJĄ CYKLU KOMÓRKOWEGO}

Jedną $z$ podstawowych cech komórek starych jest ich trwałe zatrzymanie w cyklu komórkowym. Komórki zatrzymane sa fazach G1 i/lub G2 w zależności od ich typu, rodzaju starzenia oraz czynnika indukującego. Chociaż nie musi to być reguła, to jednak zwykle podczas starzenia replikacyjnego komórki akumulują się w fazie G1, natomiast starzenie przyspieszone prowadzi do gromadzenia się komórek $\mathrm{w}$ fazie $\mathrm{G} 1 \mathrm{i}$ G2 (AlsTER i KORWEK 2014). W przypadku niektórych typów komórek nowotworowych zdarza się, iż wchodza one w nieprawidłowy cykl komórkowy i na skutek tego staja się poliploidalne (ŚLIWIŃSKA i współaut. 2009, MOSIENIAK i współaut. 2015).

Skutkiem starzenia komórkowego jest zmiana poziomu ekspresji białek. Obserwuje się wzrost ekspresji przede wszystkim białek zaangażowanych $\mathrm{w}$ zahamowanie cyklu komórkowego. Silnie wyrażone moga być białka zaangażowane w naprawę podwójnych pęknięć w DNA. Zmienia się też poziom wielu innych białek, które nie sa bezpośrednio zwiazane $z$ indukcja procesu starzenia, $\mathrm{np}$. białek cytoszkieletu.

\section{ZNACZNIKI ZWIAZZANE Z DNA I CHROMATYNĄ ORAZ FENOTYP SEKRECYJNY}

Częsta przyczyna starzenia komórkowego sa uszkodzenia pojawiajace się w jej materiale genetycznym. Najistotniejsze dla indukcji procesu starzenia sa pęknięcia dwuniciowego DNA. Takie zmiany prowadza do trwałej aktywacji ścieżki odpowiedzi na uszkodzenia DNA (ang. DNA damage, DDR). W efekcie, w komórkach starych można zidentyfikować skupiska białek należących do tej ścieżki przesyłania sygnału, między innymi aktywnej kinazy ATM, ufosforylowanego histonu H2AX ( $\mathrm{HH} 2 \mathrm{AX})$ czy białka 53BP1. Białka te sa zaangażowane w rozpoznanie miejsc uszkodzenia i ich naprawę (ALSTER i KoRWEK 2014). Przez wiele lat sądzono, że prowadzace do starzenia uszkodzenia DNA moga występować zarówno w odcinku telomerowym, jak i nietelomerowym, jednak wykazano, iż to uszkodzenia w odcinkach telomerowych przyczyniają się do trwałej aktywacji DDR i pojawienie się nawet kilku $z$ nich w tym obszarze jest istotnym impulsem do indukcji starzenia (FumAGALLI i współaut. 2012).

Jedna $z$ istotnych cech komórek ulegajacych starzeniu jest zdolność do wydzielania

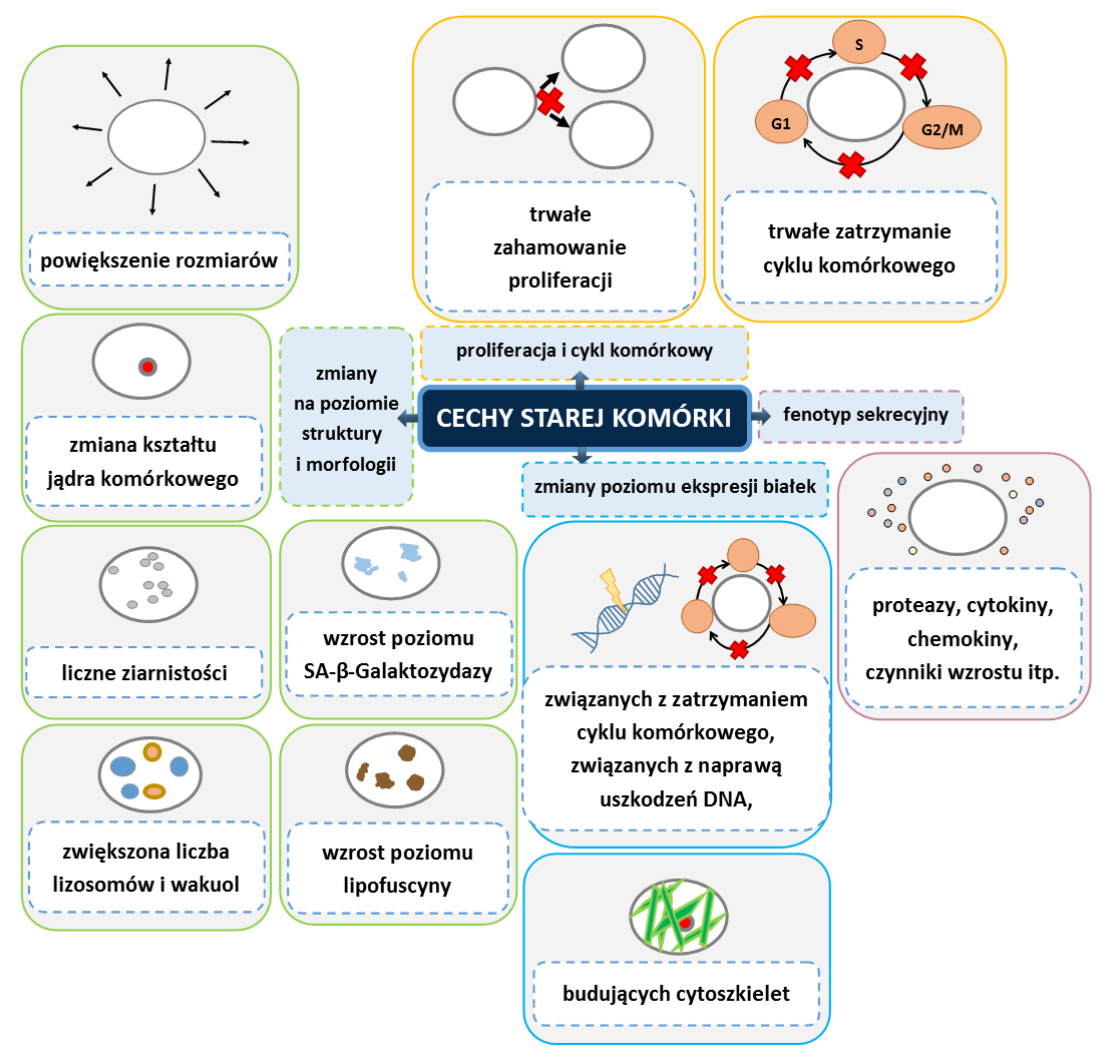

Ryc. 4. Schemat przedstawiajacy cechy komórki starej na poziomie jej struktury i morfologii, zmian jakie zachodza w proliferacji oraz cyklu komórkowym, ekspresji określonych białek oraz charakterystycznego fenotypu sekrecyjnego. 
różnego typu czynników do otaczającego je mikrośrodowiska. Tę cechę określa się mianem fenotypu sekrecyjnego określanego jako SASP (ang. senescence associated secretory phenotype) lub SMS (ang. senescence-messaging secretome). W jego skład wchodza proteazy, cytokiny, chemokiny, czynniki wzrostu itp., które działają zarówno autokrynnie, jak i parakrynnie na sassiadujace komórki. Wydzielane przez stare komórki czynniki moga wpływać pozytywnie lub negatywnie na zachodzace $\mathrm{w}$ organizmie procesy, w zależności od kontekstu tkankowego.

Między innymi zaangażowane sa w indukcję proliferacji i różnicowania komórek, angiogenezy, biora udział $w$ naprawie tkanek, transformacji epitelialno-mezenchymalnej, ale té̇ moga przyczyniać się do oporności na chemioterapię. Jedna $z$ istotnych funkcji fenotypu sekrecyjnego jest komunikowanie się komórek starych $z$ komórkami układu odpornościowego. Wykazano, że przyczynia się to do usuwania komórek starych z tkanki, w której się gromadzą (ALSTER i KORWEK 2014) (Ryc. 4).

\section{STARZENIE KOMÓRKOWE W TERAPII PRZECIWNOWOTWOROWEJ}

Starzenie komórkowe stanowi barierę przeciwnowotworowa. W procesie nowotworzenia dochodzi do przełamania tej bariery. W unieśmiertelnionych komórkach podczas kolejnych etapów kancerogenezy może dochodzić do transformacji nowotworowej. Przyczyna tego sa gromadzace się mutacje występujace w genach kodujacych takie białka jak: p53, pRb, p16, które maja ważny udział $\mathrm{w}$ indukcji starzenia komórkowego. Zauważono jednak, iż pomimo tego, że komórki nowotworowe nie podlegaja limitowi Hayflicka i nie ulegaja starzeniu replikacyjnemu, to pozostaja wrażliwe na indukcję starzenia przyspieszonego, zachodzacego pod wpływem różnych czynników chemicznych i fizycznych. Stare komórki nowotworowe zidentyfikować można przy pomocy takich samych markerów, jakie używane sa do oceny komórek prawidłowych, które uległy starzeniu (MOSIENIAK i STRZESZEWSKA 2014). Badania przeprowadzone przez Roninsona (RoNINSON 2003, RONINSON i DOKMANOVIC 2003) wykazały, że do najbardziej efektywnej indukcji starzenia komórek nowotworowych dochodzi na skutek stosowania czynników uszkadzajacych DNA, takich jak doksorubicyna lub cisplatyna. Natomiast niewielki efekt przynosiło użycie Taxolu i winkrystyny, których działanie wiąże się $z$ zaburzeniem powstania wrzeciona podziałowego. Co ciekawe, badania CHANGA i współaut. (1999) pokazały, iż do indukcji starzenia komórko- wego dojść może pod wpływem zastosowania dużo niższych stężeń związków, w porównaniu $z$ tymi, które potrzebne sa do indukcji śmierci komórki. W celu indukcji starzenia w komórkach nowotworowych można stosować również inne metody. Jedna $z$ nich stanowia manipulacje genetyczne, powodujace nadekspresję genów kodujacych białka biorace udział w hamowaniu cyklu komórkowego, takich jak: p21, p16, p57, p27, p15, geny supresorów nowotworowych: pRb, p53 czy p63, p73. Zauważono też, że do starzenia dochodziło również na skutek wprowadzenia genów kodujacych stale aktywne formy kinaz RAF-1 i MKK, a także po poddaniu komórek działaniu czynników różnicujacych, takich jak np. pochodne witaminy A (RONINSON 2003, RONINSON i DOKMANOVIC 2003). Inne badania wskazuja na to, że w komórkach nowotworowych białka takie jak p53, p21, p16 sa pozytywnymi regulatorami procesu starzenia komórkowego, ale nie sa niezbędne do jego indukcji. Wskazuje to na fakt, iż istnieja alternatywne ścieżki przesyłania sygnału prowadzace do starzenia komórek nowotworowych. Badania $Z$ użyciem tkanek pobranych od pacjentów, którzy poddani byli chemioterapii wykazały, iż do starzenia komórek nowotworowych dochodzi także podczas leczenia. Co więcej, badania przeprowadzone na myszach dowiodły, że proces starzenia komórkowego może determinować skuteczność terapii (SCHMITT i współaut. 2002).

W komórkach nowotworowych, które uległy starzeniu komórkowemu, tak samo jak w komórkach prawidłowych, dochodzi do zatrzymania proliferacji, co jest niezwykle pożądanym efektem terapii przeciwnowotworowej i może prowadzić do ograniczenia wzrostu guza. Ponadto, stare komórki nowotworowe wydzielają szereg chemokin, które mobilizuja komórki układu odpornościowego, przyczyniając się do eliminacji komórek guza (IANNELLO i współaut. 2013, XUE i współaut. 2007).

Podsumowujac, starzenie komórkowe stanowi barierę przeciwnowotworowa, a także często sprzyja powodzeniu terapii przeciwnowotworowych, czego dowodem sa m.in. badania prowadzone przez HAUGSTETTERA i współaut. (2010), pokazujące korelację pomiędzy obecnościa ulegających starzeniu komórek nowotworowych raka okrężnicy a dłuższa przeżywalnością pacjentów poddanych chemioterapii. $Z$ drugiej strony, należy brać pod uwagę ryzyko, że komórki nowotworowe, które uległy starzeniu komórkowe$\mathrm{mu}$ indukowanemu stresem moga odzyskać zdolność do ponownych podziałów (ŚLIWINSKA i współaut. 2009, MOSIENIAK i współaut. 2015). Pomimo tego uważa się, iż starzenie 
komórek nowotworowych, do którego indukcji wykorzystywać można kilka ścieżek molekularnych, stanowi interesujacy cel terapii przeciwnowotworowych, niosacy ze soba wiele nadziei, ale wymagajacy jeszcze wielu badań.

\section{OKSYDAZY NADPH A HAMOWANIE PROLIFERACJI I STARZENIE KOMORKOWE}

Jak wspomniano wcześniej, podwyższony poziom oksydaz NADPH może odgrywać istotna rolę $\mathrm{w}$ transformacji nowotworowej i w rozwoju nowotworu. $Z$ tego względu podjęto badania mające na celu określenie wpływu inhibitora oksydaz (chlorek difenylenodionoiowy, DPI) na komórki nowotworowe.

Wykazano, że podanie DPI hamuje proliferacje komórek nowotworowych raka okrężnicy (DoRoshow i współaut. 2013). Co ważniejsze, podobny efekt zaobserwowano w badaniach prowadzonych na mysich modelach nowotworzenia, w których wzrost guzów był badany in vivo. SCAIFE (2005) w badaniach prowadzonych na komórkach nowotworowych raka piersi MCF-7 zaobserwował, że komórki zatrzymane na $48 \mathrm{~h}$ w cyklu komórkowym po podaniu DPI, nie wznawiaja proliferacji nawet jeśli sa hodowane przez kilka dni w pożywce bez inhibitora. Jednak nie wykazano obecności komórek ulegających starzeniu $w$ badanym modelu. SoNG i współaut. (2008) zauważyli, że DPI blokuje przejście komórek $z$ fazy $G 1$ do fazy $S$. Zaś badania VENKATACHALAMA i współaut. (2008) dowiodły, że obserwowany efekt wpływu DPI na przechodzenie $z$ fazy G1 do S może wynikać $z$ hamujaccego wpływu właśnie na oksydazy NADPH. Podobnie DROsHOw i współaut. (2012) w pracy opisujacej wpływ DPI na komórki nowotworowe (60 różnych linii) wykazali, że niższe dawki inhibitora przyczyniaja się do hamowania cyklu komórkowego w fazie G1. Z kolei, zarówno HONG i współaut. (2007), jak i ScAIFE (2005) twierdzili, że podanie DPI prowadzi do zahamowania cyklu komórkowego w fazie G2. Efekt ten może być spowodowany zarówno opóźnionym przejściem $\mathrm{z}$ fazy $\mathrm{G} 2$ do $\mathrm{M}$, tak jak to opisano w pracy VENKATACHALAMA $i$ współaut. (2008), jak i przyspieszonym wyjściem $z$ fazy $M$, który następuje bez prawidłowo zakończonego podziału mitotycznego i prowadzi do wejścia komórek w fazę tzw. tetraploidalnego G1 (4NG1), co przedstawiono w pracy ScAifEgo (2004).

Należy jednak zauważyć, że stosowany powszechnie w wielu modelach eksperymentalnych inhibitor NOX-DPI, nie jest specyficzny tylko dla tych enzymów, ale działa również na inne flawoenzymy obecne w ko- mórce. Co istotne, niedawno opublikowane wyniki badań dowodza, że zahamowanie proliferacji komórek nowotworowych po podaniu DPI może wynikać $z$ wpływu tego zwiąku na łańcuch oddechowy, szczególnie na aktywność kompleksu I (OzSVARI i współaut. 2017). Dlatego na uwage zasługuja prace, w których specyficznie obniżono poziom ekspresji wybranych oksydaz NADPH. SHIMADA i współaut. (2011), prowadząc badania na liniach komórek nowotworowych raka pęcherza wykazali, że obniżenie poziomu NOX4 prowadziło do zahamowania ich proliferacji in vitro oraz ograniczało wzrost guza w badaniach prowadzonych na zwierzętach. Podobne wyniki uzyskano wykorzystujac do badań komórki raka okrężnicy. W tym wypadku zahamowanie proliferacji komórek nowotworowych było zwiazane $z$ obniżeniem poziomu NOX1 (WANG i współaut. 2011).

Podsumowujac, wiele prac wskazuje, że hamowanie aktywności oksydaz NADPH może być atrakcyjnym celem w terapii przeciwnowotworowej. Wciaż brakuje jednak bezpośrednich dowodów świadczacych o tym, że komórki nowotworowe ulegają starzeniu komórkowemu w wyniku zahamowania aktywności lub obniżeniu poziomu NOX. W świetle uzyskanych przez nas wyników (PRZYBYLSKA i współaut. 2016) dowodzacych, że zarówno podanie DPI, jak i wyciszenie ekspresji genu kodujacego NOX4 w ludzkich komórkach mięśni gładkich aorty prowadzi do starzenia komórkowego, możemy przypuszczać, że opisywane w literaturze długotrwałe zahamowanie podziałów komórek nowotworowych po podaniu inhibitorów oksydaz lub obniżeniu ich poziomu może również indukować starzenie.

\section{PODSUMOWANIE}

Oksydazy NAPDH to enzymy występujace specyficznie w określonych tkankach, zarówno prawidłowych, jak i tych, które zmienione sa nowotworowo. Przez produkowane reaktywne formy tlenu biora udział w licznych, istotnych procesach. Ich zwiazek $z$ procesem starzenia komórkowego prowadzacym do trwałego zahamowania proliferacji sprawia, że stanowia one interesujacy cel poszukiwań dotyczacych terapii przeciwnowotworowych.

$$
\text { Streszczenie }
$$

Oksydazy NADPH (NOX) są grupa enzymów występujących zarówno w prawidłowych, jak i nowotworowo zmienionych tkankach. Produkowane przez nie reaktywne formy tlenu (RFT) biora udział w wielu istotnych procesach występujących w komórce. Zauważono związek aktywności NOX $z$ procesem starzenia. Starzenie komórkowe to proces niezwykle interesujacy i występujacy powszechnie w organizmie ludzkim. Związane jest $\mathrm{z}$ trwałym zahamowaniem proliferacji, a w zdrowych 
komórkach stanowi barierę przeciwnowotworową. Pewne warunki prowadza do przyspieszonego starzenia komórek nowotworowych, co stanowi atrakcyjny cel terapii przeciwnowotworowych. Zwiazek oksydaz NADPH $z$ procesem starzenia komórkowego może być interesującym celem badań nad terapiami przeciwnowotworowymi.

\section{LITERATURA}

Alster O., KoRweK Z., 2014. Znaczniki starzenia komórkowego. Post. Biochem. 60, 138-46.

ARbiser J. L., Petros J., KLAFter R., GovindajaRan B., Mclaughlin E. R., Brown L. F., COHen C., Moses M., Kilroy S., ARnold R. S., LAMBETH J. D., 2002. Reactive oxygen generated by Nox1 triggers the angiogenic switch. Proc. Natl. Acad. Sci. USA 99, 715-720.

BAKER D. J., WiJshaKe T., TCHKONIA T., LEBRASSEUR N. K., ChILdS B. G., Sluis B., KirKLAND J. L., DEURSEN J. M., 2012. Clearance of p16 $6^{\text {Ink4a }}$ - positive senescent cells delays ageing - associated disorders. Nature 479, 232236.

BAKER D. J., ChILDS B. G., DURIK M., WiJers M. E., Sieben C. J., ZHONG J., SAltness R. A., Jeganathan K. B., Verzosa G. C., Pezeshiki A., Khazaie K., Miller J. D., VAN DEURSEN J. M., 2016.' Naturally occurring p16 $6^{\text {Ink } 4 a}$-positive cells shorten healthy lifespan. Nature 530, 184-189.

BEDARD K., KRAUSE K. H., 2007. The NOX Family of ROS-generating NADPH oxidases :physiology and pathophysiology. Physiol. Rev. 87, 245-313.

BIELAK-ŻMIJEWSKA A., GRABOWSKA W., PRZYBYLSKA D., 2014. Rola starzenia komórkowego w starzeniu organizmu $i$ chorobach zwiazanych $z$ wiekiem. Post. Biochem. 60, 147-160.

BLOCK K., GORIN Y., 2012. Aiding and abetting roles of NOX oxidases in cellular transformation. Nat. Rev. Cancer 12, 627-637.

Caillou B., Dupuy C., Lacroix L., Nocera M., TALBOT M., OHAYON R., DEME D., BIDART J. M., SCHLUMBERGER M., VIRION A., 2001. Ex pression of reduced nicotinamide adenine dinucleotide phosphate oxidase (ThoX, LNOX, Duox) genes and proteins in human thyroid tissues. J. Clin. Endocrinol. Metab. 86, 33513358.

Chang B. D., Broude E. V., Dokmanovic M., Zhu H., Ruth A., Xuan Y., Kandel E. S., Lausch E., Christov K., Roninson I. B., 1999. A senescence-like phenotype distinguishes tumor cells that undergo terminal proliferation arrest after exposure to anticancer agents. Cancer Res. 59, 3761-3767.

Chen K., Kirber M. T., Xiao H., Yang Y., Keaney J. F., 2008. Regulation of ROS signal transduction by $N A D P H$ oxidase 4 localization. J. Cell Biol. 181, 1129-1139.

Cheng G., Ritsick D., Lambeth J. D., 2004. Nox3 regulation by NOXO1, p47phox, and p67phox. J. Biol. Chem. 279, 34250-34255.

COllADO M., SERRANO M., 2006. The power and the promise of oncogene-induced senescence markers. Nat. Rev. Cancer 6,472-476.

Cross A. R., SEgal A. W., 2004. The NADPH oxidase of professional phagocytes - prototype of the NOX electron transport chain systems. Biochim. Biophys. Acta 1657, 1-22.

Doroshow J. H., JUHASZ A., GE Y., HOLBECK S., LU J., ANTONY S., WU Y., JIANG G., ROY K., 2012. Antiproliferative mechanisms of action of the flavin dehydrogenase inhibitors diphenylene iodonium and di-2-thienyliodonium based on molecular profiling of the NCI-60 human tumor cell panel. Biochem. Pharmacol. 83, 1195-1207.

Doroshow J. H., Gaur S., Markel S., Lu J., Van BALGOOY J., SYNOLD T. W., XI B., WU X., JUHASZ A., 2013. Effects of iodonium- class fla vin dehydrogeneses inhibitors on growth, reactive oxygen species production, cell cycle progression, NADPH oxidase 1 levels, and gene expression in human colon cancer cells and xenografts. Free Radic. Biol. Med. 57, 162175.

Fumagalli M., Rossiello F., Clerici M., Barozzi S., CitTaro D., Kaplunov J. M., Bucci G., Dobreva M., MatTi V., Beausejour C. M., HERBig U., LONGHESE M. P., D'ADDA DI FAGAGNA F., 2012. Telomeric DNA damage is irreparable and causes persistent DNA-damage-response activation. Nat. Cell Biol. 14, 355-365.

Georgakopoulou E. A., Tsimaratou K., EvangeLOU K., FERnANDEZ MaRcos P. J., ZOUMPOURLis V., TRougakos I. P., Kletsas D., Bartek J., Serrano M., Gorgoulis V. G., 2013. Specific lipofuscin staining as a novel biomarker to detect replicative and stress-induced senescence. A method applicable in cryo-preserved and archival tissues. Aging 5, 37-50.

GREIDER C. W., BLACKBURN E. H., 1985. Identification of a specific telomere terminal transferase activity in Tetrahymena extracts. Cell 43, 405-13.

HaugstetTer A. M., LodDenkemper C., Lenze D., GRÖNE J., STANDFUSS C., PETERsEN I., DÖRKEN B., SchmitT C. A., 2010. Cellular senescence predicts treatment outcome in metastasised colorectal cancer. Br. J. Cancer 103, 505-509.

HAYFLICK L., MOORHEAD P. S., 1961. The serial cultivation of human diploid cell strains. Exp. Cell Res. 25, 585-621.

Hong J., Kang M. K., SONG J. D., PARK Y. C., 2007. NADPH oxidase inhibitor diphenyleneiodonium induces p53 expression and cell cycle arrest in several cancer cell lines. J. Life Sci. 17, 778-782.

IANNEllo A., THOMPSON T.W., ARDOlino M., LOWE S. W., RAUlET D. H., 2013. p53-dependent chemokine production by senescent tumor cells supports NKG2D-dependent tumor elimination by natural killer cells. J. Exp. Med. 210, 2057-2069.

Juhasz A., Ge Y., Markel S., ChiU A., MatsumoTO L., VAN BALGOOY J., ROY K. DOROSHOW J. H., 2009. Expression of NADPH oxidase homologues and accessory genes in human cancer cell lines, tumours and adjacent normal tissues. Free Radic. Res. 43, 523-532.

KODAMA R., KaTO M., FURUTA S., UENO S., ZHANG Y., MATSUNO K., YABE-NishimuRA C., TANAKA E., KAMATA T., 2012. ROS-generating oxidases Nox1 and Nox4 contribute to oncogenic Ras-induced premature senescence. Genes Cells 18, $32-41$.

Koziel R., Pircher H., Kratochwil M., Lener B., HERMANN M., DENCHER N. A., JANSEN-DUERR P., 2013. Mitochondrial respiratory chain complex $I$ is inactivated by NADPH oxidase Nox4. Biochem. J. 452, 231-239.

Lener B., Koziet R., Pircher H., Hütter E., GreUSSING R., HERNDLER-BRANDSTETTER D., HERMANN M., UNTERLUGGAUER H., JANSEN-DÜRR P., 2009. The NADPH oxidase Nox4 restricts the replicative lifespan of human endothelial cells. Biochem. J. 423, 363-374.

LOU Y. W., CHEN Y. Y., HSU S. F., CHen R. K., Lee C. L., Khoo K. H., Tonks N. K., Meng T. 
C., 2008. Redox regulation of the protein tyrosine phosphatase PTP1B in cancer cells. FEBS J. $275,69-88$.

Mitsushita J., LAmBeth J. D., Kamata T., 2004. The superoxide-generating oxidase Nox1 is functionally required for Ras oncogene transformation. Cancer Res. 64, 3580-3585.

MosieniaK G., STRZESZEWSKA A., 2014. Rola starzenia komórkowego $w$ kancerogenezie $i$ terapii przeciwnowotworowej. Post. Biochem. 60,194-206.

Mosieniak G., Sliwinska M. A., Alster O., StrzeSZEWSKa A., Sunderland P., PIEChOta M., WaS H., SIKORA E., 2015. Polyploidy formation in doxorubicin-treated cancer cells can favor escape from senescence. Neoplasia 17, 882-893.

Oberley L. W., OBerley T. D., Buettner G. R., 1981. Cell division in normal and transformed cells: the possible role of superoxide and hydrogen peroxide. Med. Hypotheses 7, 21-42.

Ozsvari B., BonucCElli G., SANCHEZ-Alvarez R., FOSTER R., SOTGIA F., LisANTI M. P., 2017. Targeting flavin $\square$ containing enzymes eliminates cancer stem cells (CSCs), by inhibiting mitochondrial respiration: Vitamin B2 (Riboflavin) in cancer therapy. Aging 9, 2610-2628.

PARK H. S., LEe S. H., PARK D., LEE J. S., RYU S. H., LEE W. J., RHEE S. G., BAE Y. S., 2004. Sequential activation of phosphatidylinositol 3-kinase, beta Pix, Rac1, and Nox1 in growth factor-induced production of H2O2. Mol. Cell. Biol. 24, 4384-4394.

Pervaiz S., Cle`Ment M. V., 2002. A permissive apoptotic environment: function

of a decrease in intracellular superoxide anion and cytosolic acidification. Biochem. Biophys. Res. Comm. 290, 1145-1150.

PRZYBYLSKA D., MOSIENIAK G., 2014. Rola oksydazy NADPH NOX4 $w$ regulacji procesów proliferacji, starzenia $i$ różnicowania komórek. Post. Biochem. 60, 69-76.

PRZYBYLSKA D., JANISZEWSKA D., GOŹDZIK A., BIELAK-ZMIJEWSKA A., SUNDERLAND P., SiKORA E., MOSIENIAK G., 2016. NOX4 downregulation leads to senescence of human vascular smooth muscle cells. Oncotarget 7, 66429-66443.

RaY P. D., HuANG B. W., TSUJI Y., 2012. Reactive oxygen species (ROS) homeostasis and redox regulation in cellular signaling. Cell Signal. 24, 981-990.

Roninson I. B., 2003. Tumor cell senescence in cancer treatment. Cancer Res. 63, 2705-2715.

RONINSON I. B., DOKMANOVIC M., 2003. Induction of senescence-associated growth inhibitors in the tumor-suppressive function of retinoids. J. Cell Biochem. 88,83-94.

Roy K., Wu Y., Meitzler J. L., Juhasz A., LiU H., JiANG G., LU J., ANTONY S., DOROShOW J. H., 2015. NADPH oxidases and cancer. Clin. Sci. 128, 863-875.

SCAIFE R. M., 2004. G2 cell cycle arrest, down-regulation of cyclin $B$, and induction of mitotic catastrophe by the flavoprotein inhibitor diphenyleneiodonium. Mol. Cancer Ther. 3, 1229-1237.

SCAIFE R. M., 2005. Selective and irreversible cell cycle inhibition by diphenyleneiodonium. Mol Cancer Ther. 4, 876-884.

SchmitT C. A., Fridman J. S., YANG M., LeE S., BARANOV E., HOFFMAN R. M., LOWE S. W., 2002. A senescence program controlled by p53 and p16INK4a contributes to the outcome of cancer therapy. Cell 109, 335-346.

Sedelnikova O. A., Redon C. E., Dickey J. S., NAKAMURA A. J., GeORgakilas A. G., BonNer W. M., 2010. Role of oxidatively induced DNA lesions in human pathogenesis. Mutat. Res. 704, 152-159.

Serrano M., Lin A. W., Mccurrach M. E., Beach D., LOWE S. W., 1997. Oncogenic ras provokes premature cell senescence associated with accumulation of p53 and p16INK4a. Cell 88, 593-602.

SHAY J. W., BACCHETTI S., 1997. A survey of telomerase activity in human cancer. Eur. J. Cancer 33, 787-791.

ShimadA K., FUJII T., ANAI S., FujImoto K., KonISHI N., 2011. ROS generation via NOX4 and its utility in the cytological diagnosis of urothelial carcinoma of the urinary bladder. BMC Urol. 11, 22.

Song J. D., KIM K. M., KIM K. H., KIM C. D., KIM J. M., YOO Y. H., PARK Y. C., 2008. Differential role of diphenyleneiodonium, a flavoenzyme inhibitor, on p53-dependent and -independent cell cycle progression. Int. J. Oncol. 33, 1299-1306.

SPEnCER N. Y., YAN Z., Boudreau R. L., Zhang Y., LUO M., LI Q., TIAN X., SHAH A. M., DAVISSON R. L., DAVIDSON B., BANFI B., ENGELHARDT J. F., 2011. Control of hepatic nuclear superoxide production by glucose 6-phosphatedehydrogenase and NADPH oxidase-4. J. Biol. Chem. 286, 8977-8987.

Strzeszewska A., Alster O., Mosieniak G., CiolKO A., SIKORA E., 2018. Insight into the role of PIKK family members and NF- $\kappa B$ in DNAdamage-induced senescence and senescenceassociated secretory phenotype of colon cancer cells. Cell Death Dis. 9, 44

STURROCK A., HUECKSTEADT T. P., NORMAN K., SANDERS K., MURPHY T. M., Chitano P., WILSON K., HoIdAL J. R., Kennedy T. P., 2007. Nox4 mediates TGF-beta1-induced retinoblastoma protein phosphorylation, proliferation, and hypertrophy in human airway smooth muscle cells. Am. J. Physiol. Lung Cell Mol. Physiol. 292, L1543-L1555.

Szatrowski T. P., NATHan C. F., 1991. Production of large amounts of hydrogen peroxide by human tumor cells. Cancer Res. 51, 794-798.

Śliwińska M. A., MosieniaK G., WOLANin K., BABIK A., PiWOCKA K., MagalsKa A., SZCZEPANOWSKA J., FRONK J., SIKORA E., 2009. Induction of senescence with doxorubicin leads to increased genomic instability of HCT116 cells. Mech. Ageing Dev. 130, 24-32.

Ueno N., TAKEYA R., MiYano K., KiKuchi H., SuMIMOTO H., 2005. The NADPH oxidase Nox3 constitutively produces superoxide in a p22phox-dependent manner: its regulation by oxidase organizers and activators. J. Biol. Chem. 280, 23328-23339.

Venkatachalam P., DE TOledo S. M., PANDEy B. N., Tephly L. A., CARTER A. B., LitTle J. B., SPITZ D. R., AZZAM E. I., 2008. Regulation of normal cell cycle progression by flavin-containing oxidases. Oncogene 27, 20-31.

WANG R., DASHWOOD W. M., NIAN H., LÖHR C. V., FISCHER K. A., TSUCHIYA N., NAKAGAMA H., ASHKTORAB H., DASHWOOD R. H., 2011. $N A D P H$ oxidase overexpression in human colon cancers and rat colon tumors induced by 2-amino-1-methyl-6-phenylimidazo[4,5-b]pyridine (PhIP). Int. J. Cancer 128, 2581-2590.

WATSON J. D., 1972. Origin of concatemeric T7 DNA. Nat. New Biol. 239,197-201.

Weyemi U., LAGENTE-CHEVAlLIER O., BOUfRaQECH M., Prenois F., Courtin F., Caillou B., TalBOT M., DARDALHON M., AL GHUZLAN A., BIDART J. M., SCHLUMBERGER M., DUPUY C., 2011. ROS-generating NADPH oxidase NOX4 
is a critical mediator in oncogenic H-Ras-induced DNA damage and subsequent senescence. Oncogene 31, 1117-1129.

Wu Y., ANTONY S., HewitT S. M., JiAng G., YANG S. X., Meitzler J. L., Juhasz A., LU J., LIU H., DoRoshow J. H., RoY K., 2013. Functional activity and tumor-specific expression of dual oxidase 2 in pancreatic cancer cells and human malignancies characterized with a novel monoclonal antibody. Int. J. Oncol. 42, 1229-1238.

Xue W., Zender L., Miething C., Dickins R. A. Hernando E., Krizhanovsky V., CORDON-CAR-
DO C., LowE S. W., 2007. Senescence and tumour clearance is triggered by p53 restoration in murine liver carcinomas. Nature 445, 656660.

Yamaura M., Mitsushita J., FURUTA S., Kiniwa Y., ASHIDA A., GOTO Y., SHANG W. H., KUBODERA M., Kato M., TAKaTa M., SAIDA T., Kamata T., 2009. NADPH oxidase 4 contributes to transformation phenotype of melanoma cells by regulating G2-M cell cycle progression. Cancer Res. 69, 2647-2654.

KOSMOS Vol. 68, 1, 133-144, 2019

Katarzyna Piszczatowska, Grażyna Mosieniak

Laboratory of Molecular Bases of Ageing, Nencki Institute of Experimental Biology PAS, Pasteura 3, 09-093 Warszawa, E-mail: g.mosieniak@nencki.gou.pl

\section{NADPH OXIDASES AS A PROMISING TARGET FOR ANTICANCER THERAPY}

\section{Summary}

NADPH oxidases (NOX) are group of enzymes occurring in healthy and tumor altered tissues. Reactive oxygen species (ROS) which are produced by them take part in many essential processes in the cell. Connection between NOX activity and senescence was observed. Senescence is an extremely interesting and commonly occurring process in human organism. It is associated with irreversible inhibition of cell proliferation and in healthy cells may act as an anticancer barrier. Under some circumstances premature senescence of cancer cells may occur, what makes it attractive aim of studies towards development of anticancer therapies.

Key words: senescence, hallmarks of senescent cell, anticancer therapies, reactive oxygen species, NADPH oxidases 